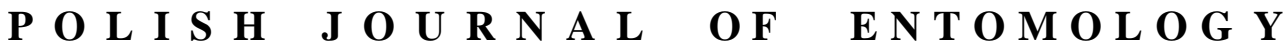

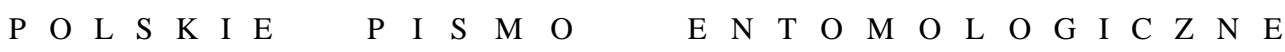

VOL. 83: $171-180$

Lublin

30 June 2014

DOI: $10.2478 /$ pjen-2014-0012

\section{Food of adult diving beetles Colymbetes fuscus (LINNAEUs, 1758) and C. striatus (LinNAEUS, 1758) (Coleoptera: Dytiscidae) in the Zehlau Peatbog and in oxbow lakes and fens (the Biebrza Marshes)}

\begin{abstract}
ANNA FRELIK
Department of Ecology and Environment Protection, Faculty of Biology and Biotechnology, University of Warmia and Mazury in Olsztyn, Pl. Łódzki 3, 10-727 Olsztyn, Poland, e-mail: aniaf2634@gmail.com

ABSTRACT. The study involved the analysis of the foregut content of 120 adult specimens of Colymbetes fuscus and C. striatus collected in aquatic habitats in the Biebrza Marshes (Poland) and the Zehlau Peatbog (Russia). The gut content comprised animals (including eggs of aquatic invertebrates), plants and detritus. Larvae of Ephemeroptera were common in beetles from the Biebrza Marshes. The gut content also included Dytiscidae, Cladocera, Chironomidae and other Diptera, Copepoda, other insects, other Coleoptera aquatica, Heteroptera, Acari, Ostracoda, Culicidae and Asellus aquaticus. In the Zehlau Peatbog, both of the beetle species fed predominantly on the larval stages of Chironomidae (Diptera). The gut content also included adult terrestrial insects and spiders.
\end{abstract}

KEY WORDS: predation, diving beetles, the Zehlau Peatbog, the Biebrza Marshes, Dytiscidae.

\section{INTRODUCTION}

Predation is one of the dominant antagonistic relationships integrating a biocoenosis. In spite of the availability of a rich literature relating to food consumed by predatory insects, our knowledge of the diet of Dytiscidae is still scarce. It is the larval stages of these beetles that seem to have been examined the most thoroughly (JOHANSSON \& NILSSON 1992, Young 1967, Young \& SPERling 1986, PeARMAN 1995, Le LOUARN \& ClOAREC 1997, GAUTAM \& GOUTAM 2006, INODA 2012). 
Field observations of the predatory behaviour of diving beetles have been carried out by, for example, SAILER \& LIENK (1954), KÜHLHORN (1961), JAMES (1965), LEE (1967), ROBERTS et al. (1967) and Young (1967). Results of studies based on the analysis of the content of intestines or proventriculi are also available. They concern mainly small and medium species (DetTNER et al. 1986, DEDING 1988, Hicks 1994, Bosi 2001, KeHL \& DETTNER 2003). The diets of representatives of the family Dytiscidae have been analysed in laboratory conditions, although according to some authors, laboratory results can be at variance with what happens in the natural environment (LINDBERG 1944, JOHNSON \& JAKINOVICH 1970, SwaMY \& RAO 1974, BISHT \& DAS 1979, IDEKER 1979, BoSE \& SEN 1985).

The objective of this study was to compare the composition of diets of Colymbetes fuscus (LinNaEus, 1758) and C. striatus (LinNAEUs, 1758) from two different localities, namely, fens in the Biebrza Marshes, distinguished by a highly diverse aquatic fauna of hydrobionts, and peatbogs in the Zehlau Peatbog, where the aquatic fauna was dominated by predaceous beetles and water bugs and the larve of acentropine moths.

\section{FIELD LOCALITIES}

The Biebrza Marshes, situated in the Biebrza National Park, constitute a unique complex of lowland wetlands with an area of $100 \mathrm{~km}^{2}$, covering the valleys of the Rivers Biebrza and Narew. A system of oxbow lakes, lying predominantly in the Biebrza valley, is a particularly interesting component of the hydrographic network. The oxbow lakes in which the beetles were captured are eutrophic water bodies inhabited by an extremely rich and diverse fauna (PAŁCZYŃSKI 1988).

The Zehlau Peatbog is located in the Kaliningrad Oblast, approximately $34 \mathrm{~km}$ north of the Polish border. More than $25 \mathrm{~km}^{2}$ in area, it includes over 200 dystrophic water bodies. The largest ones have an area of approximately 1 ha. The hydrobiological study carried out in May 1997 revealed that the local aquatic fauna was dominated by predaceous beetles and water bugs, as well as. The other groups of hydrobionts were present in small numbers (CZACHOROWSKI 1997).

\section{MATERIALS AND METHODS}

The material was collected in the Biebrza Marshes (Poland) and in the Zehlau Peatbog (Russia). The Biebrza Marshes are located at $53^{\circ} 31^{\prime} \mathrm{N}, 22^{\circ} 59^{\prime} \mathrm{E}$ and the Zehlau Peatbog is located at $54^{\circ} 32^{\prime} \mathrm{N}, 20^{\circ} 18^{\prime} \mathrm{E}$. 
Colymbetes fuscus has a length of approximately $16-18 \mathrm{~mm}$, and a relatively convex body, distinctly rounded on the edges. It usually inhabits small water bodies largely overgrown with aquatic plants. Due to its wide ecological tolerance, the beetle can colonise both peatbog and eutrophic water bodies. The eggs are laid primarily in ephemeral puddles and vernal pools with grassy vegetation. The larval stages emerge in April and May. C. striatus is of a similar size and lives in the same habitats as $C$. fuscus. Larval stages of both species are typically encountered together (GALEWSKI \& TRANDA 1978).

The material was collected by means of bottle traps (VOLKOVA et al. 2013) in May 1997 and preserved in 70\% alcohol at the Department of Ecology and Environment Protection of the University of Warmia and Mazury in Olsztyn; it was deposited in coll. Biesiadka. The traps were submerged in water without access to air. As a result, the beetles died. The material was retrieved 12 hours after the traps had been set (VOLKOVA et al. 2013). The material was analysed in 2012. A total of 120 specimens (Tab.) belonging to two species was randomly selected and the foreguts were dissected under a binocular microscope (MST 132 Edu BK). One microscope slide was prepared from each specimen. 100 specimens obtained in the Biebrza Marshes and 20 from the Zehlau Peatbog were analysed.

The contents of each specimen (number in Tab.) were immersed in a droplet of glycerine, placed in glycerine on a microscopic slide, enclosed with a cover glass and analysed under a XJS 400 microscope. One hundred slides were prepared for each of the species obtained from the Biebrza Marshes, and 20 for each of the species from the Zehlau Peatbog. The diversity of the diet of the two beetle species from different environments was analysed using the Fisher test (Statistica 2010). The results were analysed at a significance level of 0.05 , and two hypotheses were tested: $\mathrm{H}_{0}$ - the diet of $C$. striatus and $C$. fuscus from the Biebrza Marshes and the Zehlau Peatbog is the same; $\mathrm{H}_{1}$ - the diet of $C$. striatus and $C$. fuscus from the Biebrza Marshes and the Zehlau Peatbog is different.

The percentage diversity of food was calculated from the number of proventriculi in which food was identified. The percentage of animal material, plant material, other and detritus (Tab.) was calculated from the number of food items examined. The percentage contribution of particular organisms to the diet of diving beetles was calculated on the basis of their numbers in the intestinal content analysed. Such a methodology was applied in the light of the results relating to animal and plant material as well as detritus. While it is easy to determine the numbers of consumer organisms in animal material, it is impossible to do so in the case of plant material and detritus.

The items were identified from the remains of head capsules, mandibles, maxillae, eyes etc. and whole bodies in the case of Cladocera etc.

Animal and plant fragments and detritus were identified by means of a reference collection. This was produced by collecting and identifying all the organisms constituting 
the beetles potential prey. The items were macerated to a state resembling the fragments in the foreguts, and microscopic slides were made of each item.

Table. Items in the proventriculi of Colymbetes fuscus and C. striatus (n - number of Coleoptera individuals. The insect fragments are mostly from larvae; the figures in brackets relate to parts from imagines).

\begin{tabular}{|c|c|c|c|c|}
\hline \multirow[t]{2}{*}{ Taxon } & \multicolumn{2}{|c|}{ the Biebrza Marshes } & \multicolumn{2}{|c|}{ the Zehlau Peatbog } \\
\hline & $\begin{array}{c}\begin{array}{c}\text { C. fuscus } \\
\mathrm{n}=\mathbf{5 0}\end{array} \\
\end{array}$ & $\begin{array}{c}\text { C. striatus } \\
\mathrm{n}=\mathbf{5 0}\end{array}$ & $\begin{array}{c}\begin{array}{c}C . \\
\mathrm{n}=10\end{array} \\
\end{array}$ & $\begin{array}{c}\text { C. striatus } \\
\mathrm{n}=10\end{array}$ \\
\hline \multicolumn{5}{|c|}{ Animal material } \\
\hline Cladocera & 10 & 10 & 1 & - \\
\hline Ostracoda & 1 & - & - & - \\
\hline Copepoda & 6 & 2 & 1 & - \\
\hline Asellus aquaticus (LINNAEUS, 1758) & 1 & - & - & - \\
\hline Ephemeroptera & $5(3)$ & $9(1)$ & - & 1 \\
\hline Heteroptera & 2 & 2 & - & - \\
\hline Dytiscidae & $10(2)$ & 9 & 1 & 1 \\
\hline Other Coleoptera aquatica & 5 & 3 & 1 & 1 \\
\hline Trichoptera & - & - & - & 1 \\
\hline Chironomidae & 9 & 1 & 2 & $2(1)$ \\
\hline Culicidae & - & 1 & 1 & 1 \\
\hline Other Diptera & 5 & 4 & 1 & - \\
\hline Other insects & 4 & 6 & 1 & 1 \\
\hline Acari & - & 1 & - & - \\
\hline Araneae & - & - & - & 1 \\
\hline Skeletal tissue & 24 & 11 & 10 & 8 \\
\hline \multicolumn{5}{|c|}{ Plant material } \\
\hline Filamentous algae & 1 & 3 & - & - \\
\hline Mosses & - & - & 1 & 1 \\
\hline Other plant parts & - & - & - & 1 \\
\hline Seeds & 1 & - & - & - \\
\hline \multicolumn{5}{|c|}{ Detritus } \\
\hline- & 2 & 3 & 1 & - \\
\hline \multicolumn{5}{|c|}{ Other } \\
\hline Eggs & - & 11 & - & - \\
\hline \multicolumn{5}{|c|}{ Empty foreguts } \\
\hline- & 1 & 1 & - & - \\
\hline
\end{tabular}




\section{RESULTS}

The most numerous component in the foreguts of Colymbetes fuscus and C. striatus were animal organisms (84\%), predominantly insects. Apart from larval stages, a few adults were found. Eggs of aquatic invertebrates were also identified (7.1\%), and there were small proportions of plants $(5.1 \%)$ and detritus (3.8\%). No gastric content was found in 2 specimens (Tab.).

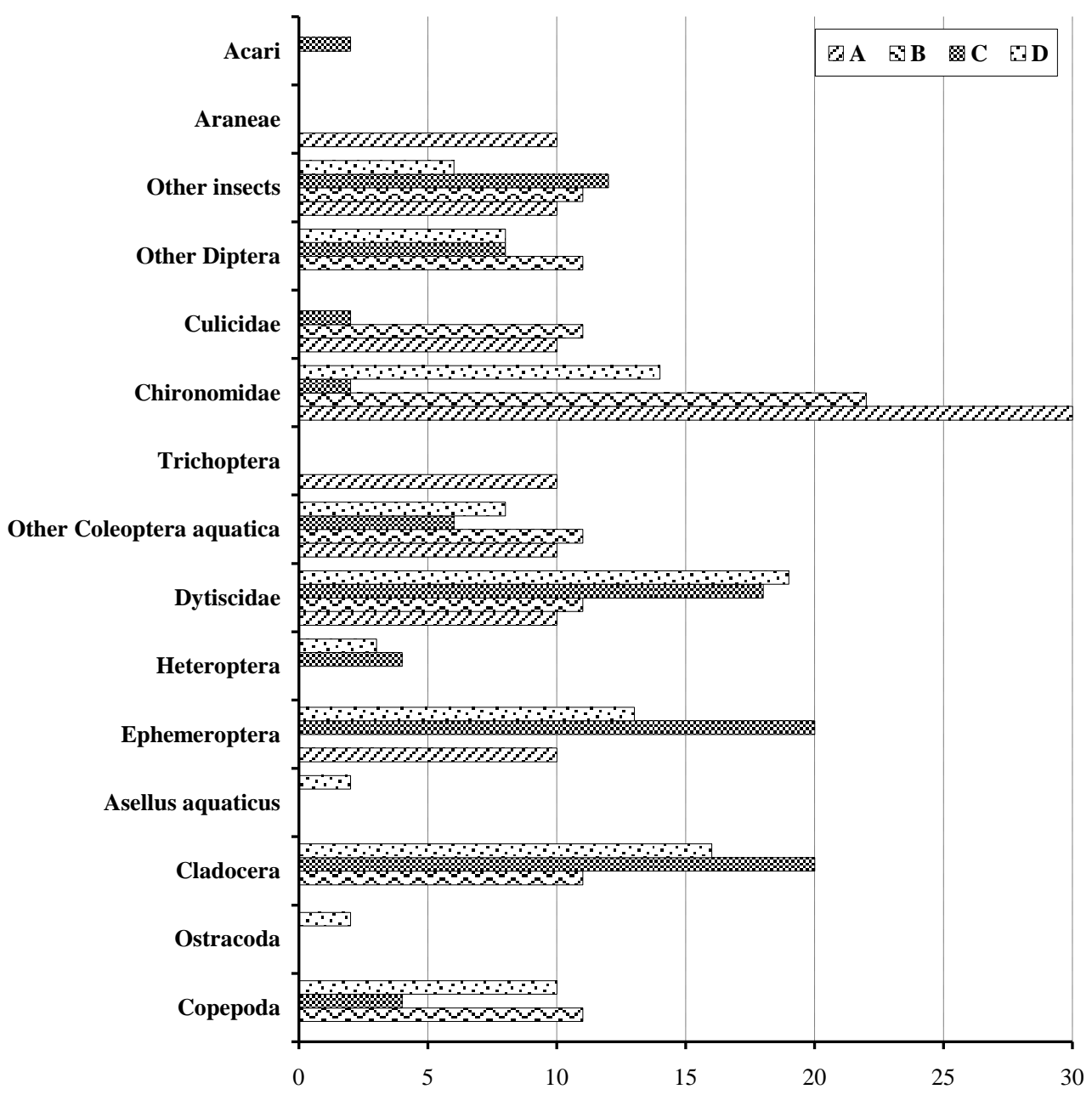

Fig. Percentage share of different food items in the foregut of Colymbetes fuscus and C. striatus (animal contents). A - C. striatus in the Zehlau Peatbog, B - C. fuscus in the Zehlau Peatbog, $\mathrm{C}-$ C. striatus in the Biebrza Marshes, D - C. fuscus in the Biebrza Marshes. 
The food ingested by the populations of $C$. fuscus and $C$. striatus from the Zehlau Peatbog contained more plant material and detritus. The population in the Biebrza Marshes ingested more adult forms of insects and striated muscle tissue (Fig.).

C. striatus more numerously consumed larval stages of Ephemeroptera and Culicidae and also adult forms of Acari and Araneae. The diet of C. fuscus contained Ostracoda, Asellus aquaticus, Cladocera and Copepoda. Moreover, the latter species consumed more adult Ephemeroptera and water beetles from the family Dytiscidae (Fig.).

The diet of diving beetles from the Biebrza Marshes comprised 13 taxa of animal organisms. Larval stages of Ephemeroptera and Chironomidae, also adult beetles from Dytiscidae and Cladocera, were consumed in the highest numbers. Larval stages of Culicidae, and adult forms of Acari, Ostracoda and Asellus aquaticus were eaten only sporadically. C. striatus ingested larval stages of Ephemeroptera and adult forms of Cladocera in the greatest abundance, while C. fuscus preferred chironomid larvae, water beetles from the family Dytiscidae and Copepoda. The diet of $C$. striatus was also found to include larval stages of Culicidae and adult forms of Acari, which were absent from the diet of $C$. fuscus. The diet of $C$. fuscus also contained Ostracoda and Asellus aquaticus (Fig.).

The diet of Coleoptera inhabiting the Zehlau Peatbog consisted of 11 taxa of organisms, dominated by larval stages of Chironomidae. Whereas $C$. striatus consumed larval stages of Trichoptera, Ephemeroptera and adult forms of Araneae, C. fuscus ingested other Diptera, Cladocera and Copepoda (Fig.).

The results of the Fisher test for Colymbetes striatus and C. fuscus from the Biebrza Marshes and the Zehlau Peatbog for particular animal organisms constituting the diet of the beetles are as follows: Ephemeroptera - 1.0; Culicidae - 1.0; Chironomidae - 0.76; other Diptera - 1.0; Dytiscidae - 1.0; other Coleoptera aquatica - 1.0; other insects - 1.0; Cladocera - 1.0; Copepoda - 1.0.

According to the Fisher test, there is no difference in the dietary composition between the two species in the two localities.

\section{DISCUSSION}

Predators in the littoral environment include piercing sucking insects and shredders. Dytiscidae imagines are shredders (ZARET 1980). They are able to ingest prey of substantially different sizes - from meiofauna to prey only slightly smaller than themselves. Shredders can also feed on organisms protected by thick integuments, e.g. a chitinous cuticle. In this case, the effectiveness of hunting and feeding depend more on the size and strength of their own mandibles and thickness of cuticles of the prey than on the relative body size of the predators and prey (ZARET 1980). This is reflected in the considerable 
variability in the size of food of the Colymbetes species analysed here. They are capable of ingesting small planktonic crustaceans and beetles with chitin cuticles, as well as winged terrestrial insects.

This situation is confirmed by LUNDKVIST et al. (2003), who demonstrated experimentally the existence of correlations between the size of the larval forms of Culicidae and their selection by Dytiscidae imagines. In spite of the prevalence in the diet of Colymbetes sp. of animal food (with a particular preference for insects), fragments of plant tissues were also consumed. Plants parts in the proventriculi of Dytiscidae were also reported by DEDING (1988), KeHL \& DETTNER (2003) and Bosi (2001). According to DEDING (1988), plants constitute a dietary supplement. They may have such a function in situations of long periods of starvation. It is also probable that the plants were ingested incidentally together with animal food.

Body fragments suggesting the ingestion of imagines of flying terrestrial insects were also frequently encountered. According to DEDING (1988), adult Diptera falling on to the water surface become an additional source of food in conditions of insufficient nutrition. Adult Diptera are particularly easy to capture while they are laying eggs in the vicinity of water bodies (DEDING 1988). Consequently, they make up a large proportion in the diet of both Colymbetes species. The presence of a spider in the diet of a single specimen suggests random selection of prey. Its consumption may have resulted from the conditions occurring in dystrophic water bodies. A low taxonomic diversity of potential prey forces predators to ingest incidentally encountered organisms.

Ephemeroptera seemed to be the preferred prey of both species recorded in the Biebrza Marshes, but a different situation occurred in the Zehlau Peatbog, where the preferred food constituted the ponderous larval stages of Chironomidae.

The results of a laboratory experiment in which beetles from the species Rhantus sikkimensis REGIMBART, 1899 were fed chironomid larval stages of various sizes were somewhat different. It turned out that the predators were more likely to choose slightly larger prey (GAUTAM \& GOUTAM 2006). In the case of the ponderous larval stages of Chironomidae, the situation is at variance with the concept of ZARET (1980). This could be due to the restriction under laboratory conditions of factors determining prey selection. Relating experimental results to natural conditions is very difficult. Hence there is an urgent need for studies on Dytiscidae imagines in the natural environment, where food selection is determined by a large number of factors.

Cladocerans were common in the diet of water beetles from the Biebrza Marshes. It is interesting that in the course of evolution, planktonic animals have developed specific adaptations protecting them from predation. In cladocerans, protection against getting eaten takes the form of a transparent body that is invisible to potential predators, irrespective of their locomotor abilities (KOPERSKI 1999). In littoral habitats, potential swimming prey is 
usually smaller, and provides a smaller energy yield per capita as food than the majority of available benthic or rather inactive animals. The significant contribution of prey with high locomotor abilities (e.g. plankton) in the diet of predators is therefore related to a considerable decrease in the weight of consumed food (KOPERSKI 1997). This fact is a perfect explanation for such large amounts of ingested Cladocera.

In both the species recorded in the Biebrza Marshes and the Zehlau Peatbog, larval forms of Dytiscidae water beetles make up a substantial proportion of their diet. Adult forms of the insects are also encountered. It is worth noting that in freshwater environments, where long food chains are the norm and cannibalism is common, predators frequently consume each other.

It is also worth emphasising that hardly any food preferences can be identified in the extreme conditions occurring in dystrophic water bodies, peatbogs, or peat pits. Life in such habitats forces organisms to develop certain adaptations related to obtaining food (BoSI 2001). It may also be a reason why imagines and juvenile forms of Dytiscidae are hunted. Moreover, terrestrial organisms drowning in water become a source of food for Dytiscidae, including beetles, spiders, or those falling on to the water surface, like dragonflies and Diptera. This was confirmed by DEDING (1988), who pointed out the occurrence of remains of aphids and chironomid imagines in the intestines of Dytiscidae.

A large proportion of the bodies of other prey items remain undigested because of the presence of chitin structures. After digesting the soft body parts of the prey, head capsules, legs, head appendages, wing cases, setae and parts of post-abdomens are left over. In the majority of cases, they are strongly fragmented. Single sclerites and their entire groups also occur. This fact is confirmed by DeDing (1988) and KeHL \& DetTNER (2003). These authors observed undigested, strongly fragmented, chitinous parts of insect bodies left over in proventriculi. It is interesting that prey items that could be used by predators to a maximum degree are frequently unavailable to them.

Even though many experimental studies of predation in diving beetles have been carried out, there is a need for more field research in order to gain deeper insight into this problem.

\section{REFERENCES}

Bisht R.S., DAS S.M. 1979. Observations on the food and feeding of some Dytiscidae (Coleoptera) of Kumaon Lakes with notes of their ecology. Journal of the Inland Fisheries Society of India 11(1): $83-86$.

BoSE K. C., SEN N.S. 1985. Studies on the preferential feeding habits of the common water beetle, Cybister tripunctatus asiaticus (SHARP) (Dytiscidae: Coleoptera). Bangladesh Journal of Zoology 13(1): 61-62. 
Bosi G. 2001. Observations on Colymbetine predation based on crop contents analysis in three species: Agabus bipustulatus, Ilybius subaeneus, Rhantus suturalis (Coleoptera: Dytiscidae). Bollettino della Societa Entomologica Italiana 133(1): 37-42.

Czachorowski S. 1997. Monitoring station over a peat bog Celau. Eko-Bałtyk 2(51): 21-22. (in Polish)

DEDING J. 1988. Gut content analysis of diving beetles (Coleoptera: Dytiscidae). Natura Jutlandica 22(10): 177-184.

Dettner K., Hübner M., Classen R. 1986. Age Structure, Phenology and Prey of Some Rheophilic Dytiscidae (Coleoptera). Entomologica Basiliensia 11: 343-370.

Galewski K., Tranda E. 1978. Freshwater fauna of Poland, Vol. 10. The water beetles, Coleoptera. PWN, Warszawa - Poznań. (in Polish)

Gautam A., Goutam K.S. 2006. Predation of the beetle Rhantus sikkimensis (Coleoptera: Dytiscidae) on the larvae of Chironomus MEIGEN (Diptera: Chironomidae) of the Darjeeling Himalayas of India. Limnologica 36(4): 251-257.

HICKS B.J. 1994. Foregut contents of adult Ilybius ERICHSON (Coleoptera: Dytiscidae) from Newfoundland. The Coleopterists Bulletin 48(2): 199-200.

IDEKER J. 1979. Adult Cybister fimbriolatus are predaceous (Coleoptera: Dytiscidae). The Coleopterists Bulletin 33(1): 41-44.

INODA T. 2012. Predaceous diving beetle, Dytiscus sharpi sharpi (Coleoptera: Dytiscidae) larvae avoid cannibalism by recognizing prey. Zoological Science 29(9): 547-52.

JAMES H.G. 1965. Predators of Aedes atropalpus (CoQ.) (Diptera: Culicidae) and of other mosquitoes breeding in rock pools in Ontario. Canadian Journal of Zoology 43(1): 155-159.

JohANSSON A., Nilsson A.N. 1992. Dytiscus latissimus and D. circumcinctus (Coleoptera, Dytiscidae) larvae as predators on three case-making caddis larvae. Hydrobiologia 248(3): 201-213.

Johnson G.H., JaKinOvich W. Jr. 1970. Feeding Behavior of the Predaceous Diving Beetle Cybister fimbriolatus fimbriolatus (SAY). BioScience 20(20): 111.

Kehl S., DetTner K. 2003. Predation by pioneer water beetles (Coleoptera, Dytiscidae) from sandpit ponds, based on crop-content analysis and laboratory experiments. Archiv für Hydrobiologie 158(1): 109-126.

KOPERSKI P. 1997. Changes in feeding behaviour of the larvae of the damselfly Enallagma cyathigerum in response to stimuli from predators. Ecological Entomology 22(2): 167-175.

KOPERSKI P. 1999. The food strategies of freshwater predators. Kosmos 48(4): 425-434. (in Polish)

KÜHLHORN F. 1961. Investigations on the importance of various representatives of the hydrofauna and flora as natural limiting factors for Anopheles larvae. Zeitschrift für angewandte Zoologie 48 $129-161$.

Le Louarn H., Cloarec A. 1997. Insect predation on pike fry. Journal of Fish Biology 50(2): $366-370$.

LEE F.C. 1967. Laboratory observations on certain mosquito predators. Mosquito News 27(3): 332-338. 
LINDBERG H. 1944. Ökologisch-geographische Untersuchungen zur Insektenfauna der Felsentümpel an den Küsten Finnlands. Acta Zoologica Fennica 41: 1-178.

LundKVist E., LANDin J., JACKSON M., Svenson C. 2003. Diving beetles (Dytiscidae) as predators of mosquito larvae (Culicidae) in field experiments and in laboratory tests of prey preference. Bulletin of Entomological Research 93(3): 219-226.

PAŁCZYŃSKi A. 1988. Biebrza Marshes. PWN, Warszawa. (in Polish)

PEARMAN P.B. 1995. Effect of pond size and consequent predator density on two species of tadpoles. Oecologia 102(1): 1-8.

RoberTs D.R., SMITH L.W., ENNS W.R. 1967. Laboratory observations on predation activities of Laccophilus beetles on the immature stages of some dipterous pests found in Missouri oxidation lagoons. Annals of the Entomological Society of America 60(5): 908-910.

SAILER R.I., LIENK S.E. 1954. Insect predators of mosquito larvae and pupae in Alaska. Mosquito News 14(1): 14-16.

Swamy C.G., Rao K.H. 1974. Studies on the feeding habits of Eretes sticticus (L.) (Dytiscidae Coleoptera). Current Science 43(7): 220-222.

Volkova P., Dzhafarova A., Fedorova D., Gladchenko M., Karnayeva A., Pozdnyakov O., Slobodkina Y., Tilipman D., Petrov P. 2013. Effect of two types and different quantities of bait on the efficiency of funnel traps for diving beetles (Coleoptera: Dytiscidae) with special emphasis on Graphoderus bilineatus DEGEER, 1774. Latvijas Entomologs 52: 119-129.

Young A.M. 1967. Predation in the larvae of Dytiscus marginalis LinNAEus (Coleoptera: Dytiscidae). Pan-Pacific Entomologist 43: 113-117.

YOUNG J.O., SPERLING S.M. 1986. The incidence of predation on lake-dwelling leeches. Freshwater Biology 16(4): 465-477.

ZARET J. 1980. Predation and freshwater communities. Yale University Press, New Haven.

Received: 3 January 2014

Accepted: 8 April 2014 